\title{
SHIVs, monkeys, and anti-HIV-1 neutralizing antibodies
}

\author{
Malcolm A Martin \\ From Frontiers of Retrovirology: Complex retroviruses, retroelements and their hosts \\ Cambridge, UK. 16-18 September 2013
}

One of the major obstacles in developing an effective HIV vaccine has been the inability to design immunogens capable of eliciting broadly reacting neutralizing antibodies (NAbs). We have previously described the construction and properties of the pathogenic R5-tropic $\mathrm{SHIV}_{\mathrm{AD} 8}$, which expresses the envelope glycoprotein derived from HIV- $1_{\text {Ada }}$ strain and exhibits a Tier 2 neutralization phenotype. During its characterization, we discovered that SHIV $_{\mathrm{AD} 8}$ had unique properties: nearly all infected rhesus monkeys generated broadly reacting NAbs capable of blocking the infection of Tier 1 HIV-1 isolates. Furthermore, approximately $25 \%$ of infected animals developed Nabs against Tier 2 HIV-1 strains, and one infected macaque was an "elite neutralizer", producing potent, crossclade NAbs that targeted the gp120 N332 glycan. We have used the $\mathrm{SHIV}_{\mathrm{AD} 8}$ macaque system as an animal model to investigate the steps associated with the production of broadly reacting anti-HIV-1 NAbs including the role of follicular helper $\mathrm{T}$ cells. In a final group of experiments, the role of new potent, broadly acting, anti-HIV monoclonal NAbs to block virus acquisition or as immunotherapy in chronically infected animals will be presented.

Submit your next manuscript to BioMed Central and take full advantage of:

- Convenient online submission

- Thorough peer review

- No space constraints or color figure charges

- Immediate publication on acceptance

- Inclusion in PubMed, CAS, Scopus and Google Scholar

- Research which is freely available for redistribution 